\title{
Fyn kinase-tubulin interaction during meiosis of rat eggs
}

\author{
A Talmor-Cohen, R Tomashov-Matar, W B Tsai ${ }^{1}$, W H Kinsey ${ }^{1}$ and R Shalgi \\ Department of Cell and Developmental Biology, Sackler Faculty of Medicine, Tel Aviv University, \\ Ramat-Aviv 69978 Tel-Aviv, Israel and ${ }^{1}$ Department of Anatomy and Cell Biology, University of Kansas Medical \\ Center, Kansas City, Kansas 66160, USA \\ Correspondence should be addressed to R Shalgi; Email: shalgir@post.tau.ac.il
}

\begin{abstract}
Prior to fertilization, the spindle of vertebrate eggs must remain stable and well organized during the second meiotic metaphase arrest (MII). In a previous study we have determined that the completion of meiosis is a Src family kinase (SFK)-dependent event. In the current study we have used the SFK inhibitors, SU6656 and PP2, and demonstrated that inhibition of SFKs caused the formation of a disorganized spindle. The observation that proper organization of an MII spindle is an SFK-dependent process, combined with our previous finding that Fyn kinase is localized at the microtubules (MTs), prompted us to examine the potential role of Fyn in MT signaling. Our results show an association between Fyn and tubulin, the ability of Fyn to phosphorylate tubulin in vitro and stimulation of meiosis completion by injection of a constitutively active form of Fyn (CAF).

We suggested that SFKs mediate significant functions during the organization of the MII spindle. In view of CAF injection experiments, and of the pronounced concentration of Fyn kinase at the spindle, we propose that Fyn may play an important role in some aspects of the spindle functions, possibly those involving the MTs.

Reproduction (2004) 128 387-393
\end{abstract}

\section{Introduction}

Ovulated rat eggs arrest at the metaphase of the second meiotic division (MII). During the arrest phase, the chromosomes remain aligned at the metaphase plate, awaiting sperm-induced egg activation that would trigger their segregation, among other processes. The meiotic spindle which originates from the microtubule organizing centers (MTOCs), is barrel shaped, and is devoid of astral microtubules (MTs). Not much is known about the precise mechanism that enables the spindle of an MII-arrested mammalian egg to remain correctly organized. The MII arrest is mediated by the mitogen-activated protein kinase (MOS/...MAPK) pathway and has been extensively studied, especially in relation to the aspect of the M-phasepromoting factor (MPF; a complex of cdc2 and cyclin B). Indeed, during the MII arrest, MPF levels remain high, owing to the cytostatic factor (CSF) activity generated by the MOS/...MAPK pathway that controls the organization of MTs as well (Terret et al. 2003). The achievement of a normally developed embryo - as a result of a successful fertilization process - relies, among other things, on the proper organization of MTs in MII eggs.

Src family protein tyrosine kinases (SFKs) are implicated in a variety of cellular processes. SFKs are cytoplasmic enzymes, linked to the cell membrane via amino-terminal fatty acids. They are composed of one src homology 2 $(\mathrm{SH} 2)$ domain, one src homology 3 (SH3) domain, a catalytic domain and a carboxy-terminal regulatory sequence (Superti-Furga \& Courtneidge 1995). Their function at fertilization is currently under investigation. There is increasing evidence that SFKs play an important role in regulating mitotic events. Fyn, c-Src and c-Yes are activated in response to various growth factors during the transition from the G0 to the G1 phase of the cell cycle (Kypta et al. 1990, Courtneidge et al. 1993, Rongish \& Kinsey 2000). The three SFKs are also activated in fibroblasts during the late G2 phase and during the entry into mitosis (Roche et al. 1995a). Furthermore, microinjection of antibodies which neutralize c-Src, c-Yes and Fyn in NIH3T3 cells, inhibits entry into mitosis, suggesting that the catalytic activity of SFKs is necessary for initiation of mitosis (Roche et al. 1995b). Progression of the cell cycle is blocked by inhibition of SFKs (Moasser et al. 1999). These studies demonstrate the requirement of SFKs for entry into mitosis, suggesting that interactions among the $\mathrm{SH} 2$ domain of the SFKs, the signaling-tyrosine-phosphorylating (STP) proteins and the cytoskeletal proteins, are necessary for mitotic cell division in fibroblasts.

Changes in activity and localization of c-Src during mitosis, suggest a mitotic function (David-Pfeuty \& Nouvian-Dooghe 1990, 1995, Bagrodia et al. 1991, Zhao 
et al. 1992, Taylor \& Shalloway 1993, David-Pfeuty et al. 1993). An increase in the tyrosine phosphorylation of a $68 \mathrm{kDa}$ protein is observed during mitosis, concomitant with an increase in C-Src activity (Fumagalli et al. 1994, Taylor \& Shalloway 1994). Localization of c-Src to fibroblastic endosomes and to MT structures, implies c-Src involvement in protein trafficking and in mitotic centriol organization (David-Pfeuty \& Nouvian-Dooghe 1990, Kaplan et al. 1992). Fyn kinase was found to be associated (Katagiri et al. 1993, Marie-Cardine et al. 1995) or colocalized (Ley et al. 1994, Yasunaga et al. 1996) with the spindle MTs during the M-phase of various cells.

Although the function of the specific SFKs is unclear at present, their subcellular localization has provided some clues. Localization of c-Src, c-Yes and Fyn to different compartments in the rat egg indicates that these proteins may have different functions within the egg (Talmor et al. 1998, Talmor-Cohen et al. 2004). The localization of Fyn (but not of c-Src or c-Yes) to the MTs suggests that Fyn may have a role in directing the MTs' action. The use of SFK inhibitors enabled us to inhibit the completion of the cell cycle (Talmor-Cohen et al. 2004). We may infer that SFKs in general and Fyn in particular, could control MT organization. The objective of the present study is to analyze the association of SFKs with the spindle.

\section{Materials and Methods}

\section{Oocytes and eggs}

Wistar-derived rats, 23-25 days old, were primed with $10 \mathrm{IU}$ pregnant mares serum gonadotropin (PMSG; Syncro-Part, France) and with $10 \mathrm{IU}$ human chorionic gonadotropin (hCG, Sigma). Cumulus-enclosed oocytes, either at the germinal vesicle breakdown (GVBD) or at the metaphase I (MI) stage were isolated from the large follicles 4-8 $\mathrm{h}$ after hCG administration; MII eggs, on the other hand, were isolated from the oviducts, $14 \mathrm{~h}$ after hCG administration into culture medium (TH medium; Talmor et al. 1998). Cumulus cells were removed by a brief exposure to hyaluronidase (400 IU/ml, H-3631 Sigma). MII-ovulated eggs were parthenogenetically activated by $2 \mu \mathrm{M}$ ionomycin (Calbiochem, San Diego, CA, USA).

\section{Antibodies and drugs}

Anti-Fyn-3 peptide polyclonal antibody (pAb; Santa Cruz Biotechnology, Santa Cruz, CA, USA), was chemically coupled to protein A-sepharose to prepare an immobilized antibody affinity reagent for immunoprecipitation (Talmor et al. 1998). Anti- $\beta$ tubulin monoclonal antibody (mAb) and nocodazole were purchased from Sigma. Stock solution of $2 \mathrm{mg} / \mathrm{ml}$ of nocodazole was prepared in DMSO and diluted in $\mathrm{TH}$ medium before use to a final concentration of $10 \mu \mathrm{g} / \mathrm{ml}$. Stock solutions of $13 \mathrm{mM} 4$-amino-5(4-chlorophenyl)-7-(t-butyl)pyrazolo[3,4-d]pyrimidine (PP2), PP3 and of $10 \mathrm{mM}$ SU6656 (Calbiochem-Novabiochem, CA, USA) were prepared in DMSO and diluted before use in $\mathrm{TH}$ medium to final concentrations of either 10-100 $\mu \mathrm{M}$ (PP2, PP3) or 1-5 $\mu \mathrm{M}$ (SU6656).

\section{Immunoprecipitation and immunoblotting}

Batches of 400 eggs were lysed in $100 \mu \mathrm{l}$ NP-40 lysis buffer and immunoprecipitated with anti-Fyn-3 peptide pAb, as described previously (Talmor et al. 1998). Western blot analysis was performed with an anti- $\beta$ tubulin mAb $(1: 200)$. Bound antibody was recognized by horseradish peroxidase conjugated to anti-mouse antibody (1:5000; Sigma). Detection was performed by ECL (Pierce, Rockford, IL, USA). Approximate molecular masses were determined by comparison with the migration of prestained protein standards (Amersham).

\section{CAF construction}

In order to create a form of Fyn kinase that would be constitutively active (CAF), we modified it's C-terminal phosphorylation site to a non-phosphorylatable residue. A mutation was induced in the Fyn sequence of Xenopus that substituted Tyr 532 by Phe. This was done by PCR, using a sense primer $5^{\prime}$ TAG AAT TCG ATA ATG GGC TGT GTG CAA T3' and an antisense primer $5^{\prime}$ TAG CTC GAG GTT GTC TCC AGG CTG AAA TT 3'. The PCR product was cloned into pGEX4T3 and the sequence GST$\mathrm{Fyn}^{\mathrm{y} 532 \mathrm{f}}$ was confirmed. The fusion protein was expressed in Escherichia coli and purified by affinity chromatography (GST Technical Manual; Pharmacia Biotech, Piscataway, NJ, USA). Further purification was accomplished by chromatography on a diethylaminoethyl (DEAE) column followed by elution by a $50-500 \mathrm{mM} \mathrm{KCl}$ gradient. Fractions containing protein tyrosine kinase (PTK) activity were pooled, concentrated and dialyzed to KPS buffer $(150 \mathrm{mM}$ $\mathrm{KCl}, 3 \mathrm{mM} \mathrm{NaCl}, 10 \mathrm{mM} \mathrm{KH_{2 }} \mathrm{PO}_{4}, \mathrm{pH}$ 7.2). Catalytic activity was confirmed by a kinase assay using a synthetic peptide substrate.

\section{Microinjection}

CAF was microinjected into unfertilized eggs $(\sim 10 \mathrm{pl}$ per oocyte). Control eggs were microinjected with KPS buffer alone or with a boiled CAF protein. The estimated concentration of CAF that would be within the egg cytoplasm is indicated in the Results section. Microinjections (Narishige Micromanipulators, Japan) were performed under differential interference contrast (DIC; inverted microscope TE-200, Nikon, Japan), at $\times 20$ (objective) magnification, by intracytoplasmic injection micropipettes (Perry, Medical Instrumental Development Ltd, Ra'anana, Israel). All microinjection experiments were performed on a warm stage $\left(30 \pm 0.5^{\circ} \mathrm{C}\right)$ in $\mathrm{TH}$ medium supplemented with $10 \%$ fetal calf serum (FCS; Biological Industries, BeitHaemek, Israel). The microinjected eggs were allowed $1 \mathrm{~h}$ of recovery in $\mathrm{TH}$ medium at $37^{\circ} \mathrm{C}, 5 \% \mathrm{CO}_{2}$ in air, prior to fixation (3\% paraformaldehyde and $0.01 \%$ glutaraldehyde in Dulbecco's phosphate-buffered saline (DPBS)) and 
to zona pellucida (ZP) removal. Eggs were monitored for morphological criteria that indicate progression through the activation process (the chromosomal stage was detected by a DNA-specific fluorochrome (Hoechst 33342, Sigma); cortical granules exocytosis (CGE) was detected by lens culinaris aectin (LCA) and Texas-red streptavidin (Vector; Eliyahu \& Shalgi 2002). Data are expressed as a percentage: the number of treated eggs that resumed meiosis successfully, or demonstrated CGE, per total number of injected eggs.

\section{Immunofluorescent staining and laser-scanning confocal microscopy}

Oocytes/eggs at various stages of meiosis were fixed and permeabilized (Talmor et al. 1998), then incubated in the presence of two primary antibodies: either anti-Fyn-3 peptide pAb (1:10) or anti- $\beta$ tubulin mAb (1:5000), followed by an incubation with $\mathrm{Cy}$-conjugated secondary antibodies (Jackson Immunoresearch Laboratories, West Grove, PA, USA): donkey anti-rabbit IgG-Cy2 (1:500) or donkey antimouse IgG-Cy3 (1:500) respectively. Data collected from three experiments were pooled. Groups of three to four oocytes from each experiment were recorded.

DNA was detected by Hoechst 33342. Stained oocytes/ eggs were visualized and photographed using a Zeiss confocal laser scanning microscope (CLSM; Rufas et al. 2000). The dye intensity was measured using the corrected mean density values obtained by the LSM software.

\section{In vitro phosphorylation of tubulin}

Samples of purified bovine brain tubulin $(1 \mu \mathrm{g})$ were incubated with $10 \mathrm{ng}$ GST-Fyn ${ }^{\text {y332f }}$ bound to glutathionesepharose (Pharmacia Biotech) in kinase buffer $(15 \mathrm{mM}$ HEPES, $10 \mathrm{mM} \mathrm{MgCl}$, $1 \mathrm{mM}$ 2-mercaptoethanol, $1 \mathrm{mM}$ $\left[{ }^{32} \mathrm{P}\right]$ ATP $\left.(3 \mathrm{mCi} / \mu \mathrm{mol}) ; \mathrm{pH} 7.2\right)$ for $10 \mathrm{~min}$ at $25^{\circ} \mathrm{C}$. The reaction was stopped by an addition of $2 \times$ Laemmli sample buffer and the products were resolved by SDSPAGE. The gel was treated with $1 \mathrm{M} \mathrm{KOH}$ for $1 \mathrm{~h}$ at $50^{\circ} \mathrm{C}$ to hydrolyze any P-Ser and P-Thr, then dried and analyzed by autoradiography.

\section{Statistical analysis}

The significance of differences between experimental groups was determined by Fisher's exact probability test or by one-way ANOVA test, combined with Tukey's method for multiple comparisons; $P<0.05$ was considered significant.

\section{Results}

\section{Effect of SFK inhibitors on tubulin organization within rat eggs}

Immunofluorescence confocal analysis was performed to determine the effect of SFK inhibitors (PP2, SU6656) on the organization of MTs within the egg. MII eggs were cultured in the presence of $5 \mu \mathrm{g} / \mathrm{ml} \mathrm{SU6656,100 \mu g/ml}$ PP2 or of $10 \mu \mathrm{g} / \mathrm{ml}$ nocodazole for $30 \mathrm{~min}$; they were washed, fixed and labeled with anti-tubulin and Hoechst dye. The chromosomes of MII eggs were aligned on the equatorial plane of the spindle, while the MTs constituted the meiotic spindle, which was oriented radially to the cell cortex (Fig. $1 \mathrm{~A}^{\prime}$ ). Exposure of MII eggs to $5 \mu \mathrm{M}$ SU6656 caused a disintegration of the barrel-shaped spindle and appearance of dispersed tubulin fibers
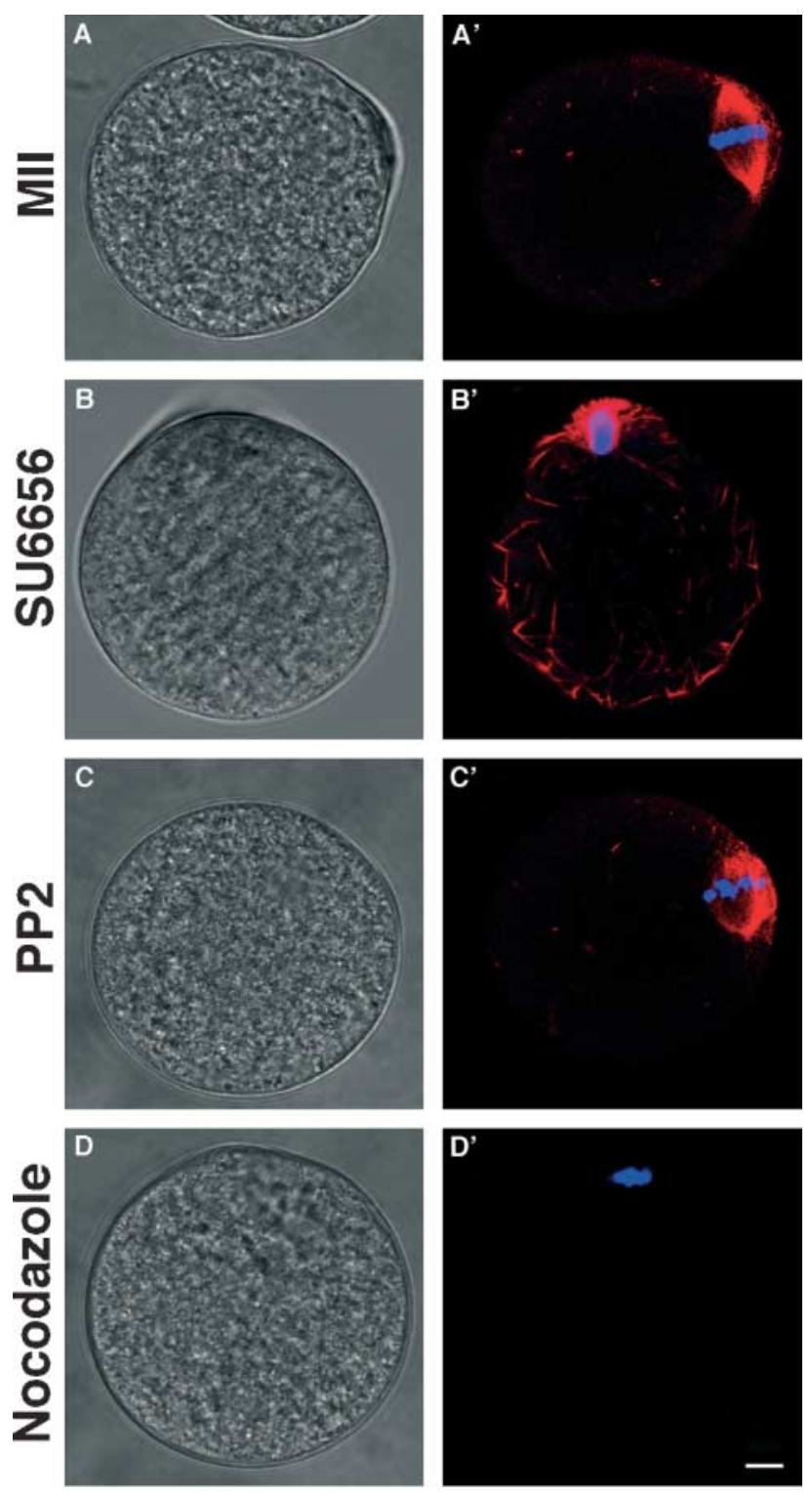

Figure 1 Effect of Src inhibitors, PP2 and SU6656, on tubulin organization. MII eggs were labeled with anti- $\beta$-tubulin antibody (1:5000) detected by fluorescent-labeled Cy secondary antibody $(1: 2500)$. DNA was labeled by Hoechst (33342, $2 \mu \mathrm{g} / \mathrm{ml})$. The localization of $\beta$-tubulin (red), and DNA (blue) was imaged using confocal microscopy. Light microscopy $(A-D)$, confocal microscopy $\left(A^{\prime}-D^{\prime}\right)$. Unfertilized (MII) egg $\left(A, A^{\prime}\right)$; MII egg incubated in the presence of $5 \mu \mathrm{g} / \mathrm{ml}$ SU6656 (B, B'), $100 \mu \mathrm{g} / \mathrm{ml} \mathrm{PP2} \mathrm{(C,} \mathrm{C')} \mathrm{or} 10 \mu \mathrm{g} / \mathrm{ml}$ nocodazole $\left(\mathrm{D}^{\prime} \mathrm{D}^{\prime}\right)$ for $30 \mathrm{~min}$. Scale bar, $10 \mu \mathrm{m}$. 
throughout the cytoplasm. Moreover, the chromosomes were no longer aligned on a metaphase plate (Fig. $1 \mathrm{~B}^{\prime}$ ). PP2 did not have such a dramatic effect on the metaphase plate but caused a minor disorganization of the spindle (Fig. 1C'). SFK inhibitors did not cause depolymerization of the MTs in MII eggs, as was the case for nocodazole (Fig. 1D'), which suggests a different mechanism of action.

\section{Fyn-tubulin association during meiosis}

In a recent study we were able to show that Fyn kinase is localized to the meiotic spindle (Talmor-Cohen et al. 2004). Immunofluorescence confocal microscopy demonstrated colocalization of a subpopulation of Fyn kinase with MTs, already at the GVBD stage. Oocytes from a representative experiment are shown in Fig. 2, demonstrating short MTs surrounding the chromosomes of an oocyte undergoing GVBD (Fig. 2A'). A bipolar spindle was observed $6 \mathrm{~h}$ post hCG injection, and the chromosomes gathered at the equatorial plane (Fig. 2B'), as in the MII stage (Fig. 2C'). As a specificity control for each experiment, a synthetic peptide antigen was coincubated with the primary antibody to act as a competitive inhibitor. The antibody staining was completely blocked by the synthetic peptide (data not shown). Our findings indicate that localization of Fyn kinase at the spindle MT is a general phenomenon, observed, in the present study, during oocyte maturation (Fig. 2A, B and C), and as shown in a previous work, during fertilization in both the meiotic and the mitotic spindles (Talmor et al. 1998).

The colocalization of Fyn kinase with the MT fibers during all stages of meiosis and mitosis could imply an association with tubulin; this was tested by the use of $10 \mu \mathrm{g} / \mathrm{ml}$ nocodazole. As could be seen by immunofluorescence confocal microscopy, the depolymerization of
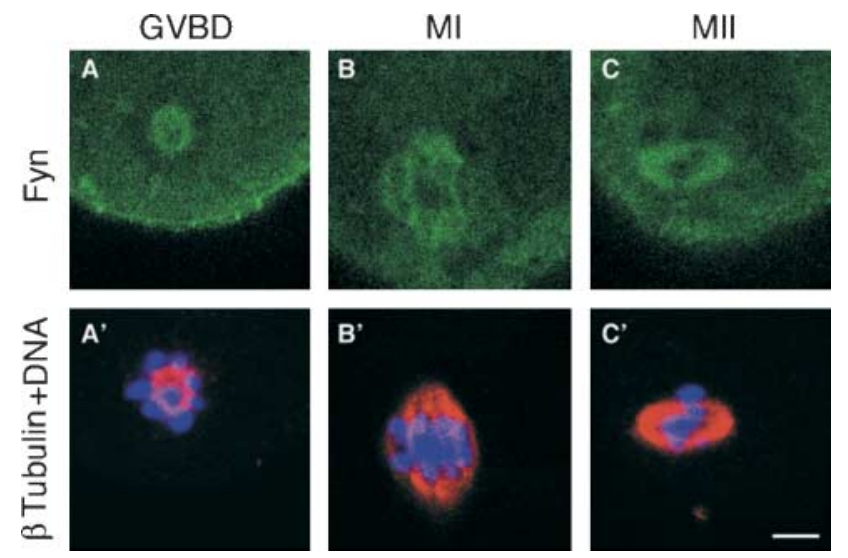

Figure 2 Localization of Fyn kinase and tubulin during meiosis. Oocytes at various stages of meiosis were double-labeled with antiFyn-3 peptide antibody (1:10; A, B and C) and anti- $\beta$-tubulin antibody $\left(1: 5000 ; A^{\prime}, B^{\prime}\right.$ and $\left.C^{\prime}\right)$. Primary antibodies were detected by fluorescent-labeled Cy secondary antibodies (1:500). DNA was labeled by Hoechst (33342, $2 \mu \mathrm{g} / \mathrm{ml}^{\prime} \mathrm{A}^{\prime}, \mathrm{B}^{\prime}$ and $\mathrm{C}^{\prime}$ ). The localization of Fyn (green), $\beta$-tubulin (red) and DNA (blue) was imaged using confocal microscopy. (A, $\left.A^{\prime}\right)$ GVBD oocyte (4 h after hCG); (B, B') Ml oocyte (6-8 $\mathrm{h}$ after hCG); (C, $\left.C^{\prime}\right)$ MIl egg (14 h after hCG). Scale bar, $10 \mu \mathrm{m}$.
MTs that occurred after incubation of the eggs in the presence of the drug, abolished the tubulin staining without affecting the chromosomal metaphase (Fig. 3B'). Nocodazole treatment caused dispersal of Fyn staining from the spindle, and was observed throughout the cytoplasm of all eggs tested (Fig. 3B); it also caused abolishment of tubulin staining (Fig. 3B' $)$. After washing off the drug most of the eggs (69/75) re-exhibited a fully recovered spindle (Fig. 3C') accompanied by Fyn staining (Fig. $3 \mathrm{C}$ ). These results suggest that the association of Fyn with the spindle MTs is dynamic and can be disrupted and re-established when MTs are allowed to depolymerize and repolymerize respectively.

The interaction between Fyn and the spindle MTs was also examined by coimmunoprecipitation of Fyn and tubulin. Fyn was immunoprecipitated from detergent extracts of batches of 400 eggs equivalent to $\sim 13 \mu \mathrm{g}$ protein. Tubulin was detected, by Western blot analysis, in samples of unfertilized and of ionomycin-activated eggs using an anti- $\beta$-tubulin antibody (Fig. 4). We were able to detect a weak tubulin band when Fyn was immunoprecipitated from lysates of non-activated MII eggs (Fig. 4, lane a). The tubulin band became more prominent after activation by ionomycin (Fig. 4, lane b). Control samples containing only culture media were devoid of any band (Fig. 4, lane c) as were samples immunoprecipitated by a nonrelated control antibody (data not shown). The detected $\beta$-tubulin band served as an indicator for the presence of the tubulin heterodimer in the precipitate.

We tested the ability of Xenopus Fyn ${ }^{\mathrm{y} 532 \mathrm{f}}$ (CAF), expressed as a GST fusion protein, to phosphorylate bovine brain tubulin in vitro, and were able to show that purified tubulin from bovine brain acts as a substrate for
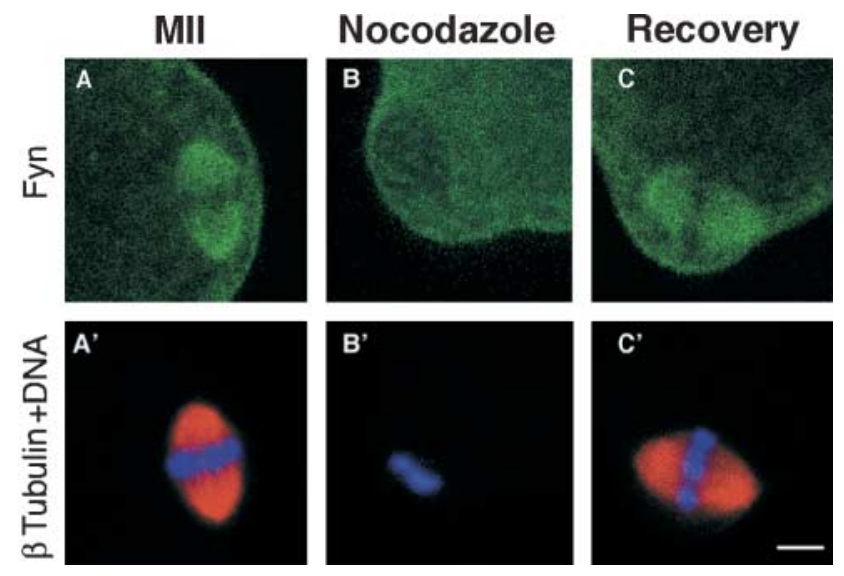

Figure 3 Effect of nocodazole on Fyn kinase localization. MII eggs were double-labeled with anti-Fyn-3 peptide antibody (1:10; A, B and $C$ ) and anti $\beta$-tubulin antibody (1:5000; $A^{\prime}, B^{\prime}$ and $\left.C^{\prime}\right)$. Primary antibodies were detected by fluorescent-labeled Cy secondary antibodies (1:500). DNA was labeled by Hoechst (33342, $2 \mu \mathrm{g} / \mathrm{ml}^{\prime} \mathrm{A}^{\prime}, \mathrm{B}^{\prime}$ and $C^{\prime}$ ). The localization of Fyn (green), $\beta$-tubulin (red), and DNA (blue) was imaged using confocal microscopy. MII egg ( $\left.A, A^{\prime}\right)$; MII egg cultured in the presence of $10 \mu \mathrm{g} / \mathrm{ml}$ nocodazole for $1 \mathrm{~h}$ and fixed immediately $\left(B, B^{\prime}\right)$ or 30 min after removal of the drug $\left(C, C^{\prime}\right)$. Scale bar, $10 \mu \mathrm{m}$. 


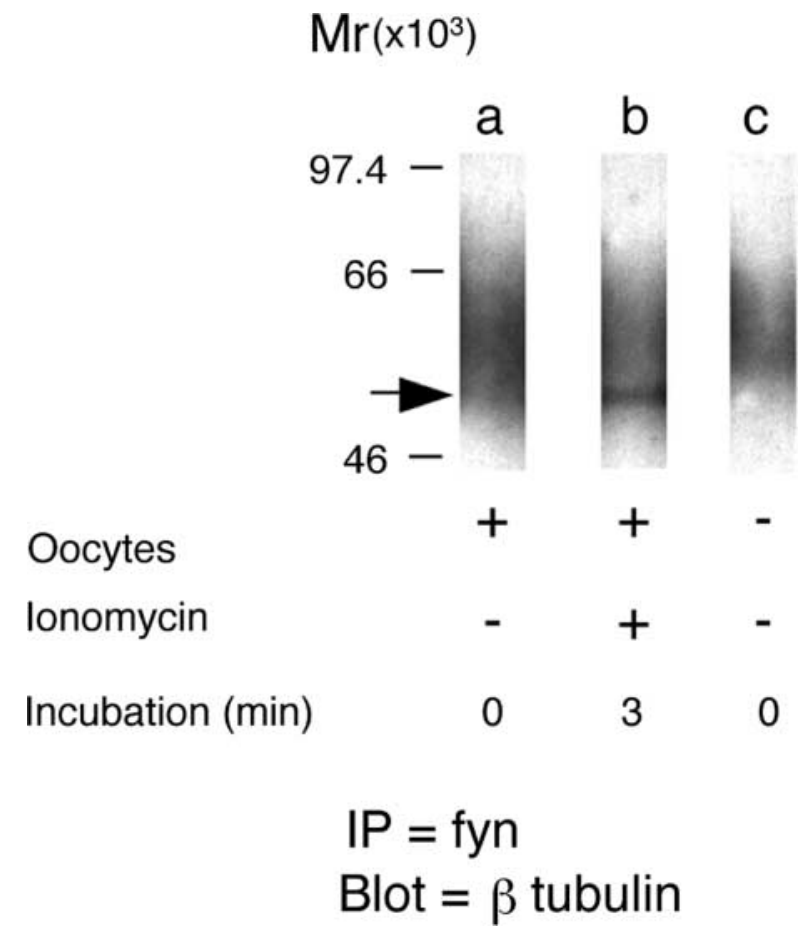

Figure 4 Association of Fyn kinase with tubulin during egg activation. Batches of 400 eggs were lysed: MII eggs (lane a), eggs activated by a 3-min ionomycin treatment (lane b), IP buffer (control; lane c). Lysates were immunoprecipitated with anti-Fyn 3 peptide antibody $(\mathrm{IP}=$ Fyn), subjected to SDS-PAGE analysis and transferred onto a PVDF membrane. The blot was probed with anti- $\beta$-tubulin antibody (blot $=\beta$-tubulin; $1: 200$ ). Bound antibody was localized by protein $A$ conjugated to horseradish peroxidase and revealed by ECL.

The results of a representative experiment demonstrate a $\beta$-tubulin band at $55 \mathrm{kDa}$ (arrow) as calculated from the migration of protein standards, with known molecular mass.

Fyn kinase. As seen in Fig. 5, the kinase reaction containing GST- Fyn ${ }^{\mathrm{y} 532 \mathrm{f}}$ resulted in a single $85 \mathrm{kDa}$ band representing the autophosphorylated kinase, although some lower molecular weight contaminants or proteolytic fragments are also phosphorylated. Tubulin alone had no kinase activity (Fig. 5, lane B). Addition of tubulin to the kinase reaction resulted in phosphorylation of a doublet (approx $45 \mathrm{kDa}$ ) representing $\alpha$ - and $\beta$-tubulin (Fig. 5, lane C). While tubulin is similar in $M_{\mathrm{r}}$ to some of the faint bands in lane $\mathrm{A}$, the $45 \mathrm{kDa}$ doublet is phosphorylated at a higher level relative to other contaminants and is therefore unlikely to represent a phosphorylated contaminant.

The results obtained so far, demonstrate the interaction between Fyn and tubulin during meiosis. To determine whether Fyn is involved in cell cycle resumption, we microinjected CAF into MIl eggs. Microinjection of CAF caused completion of meiosis and PBII extrusion (Fig. 6Ac), whereas most of the eggs injected with boiled CAF remained at the MII stage (Fig. 6Ab and B (gray bars)). Completion of meiosis in response to injection of CAF occurred in a dose-dependent fashion (Fig. 6B, black bars). Some $77 \%$ of eggs injected with $\mathrm{CAF}$ at a concentration of $555 \mu \mathrm{g} / \mathrm{ml}$ (calculated as final concentration

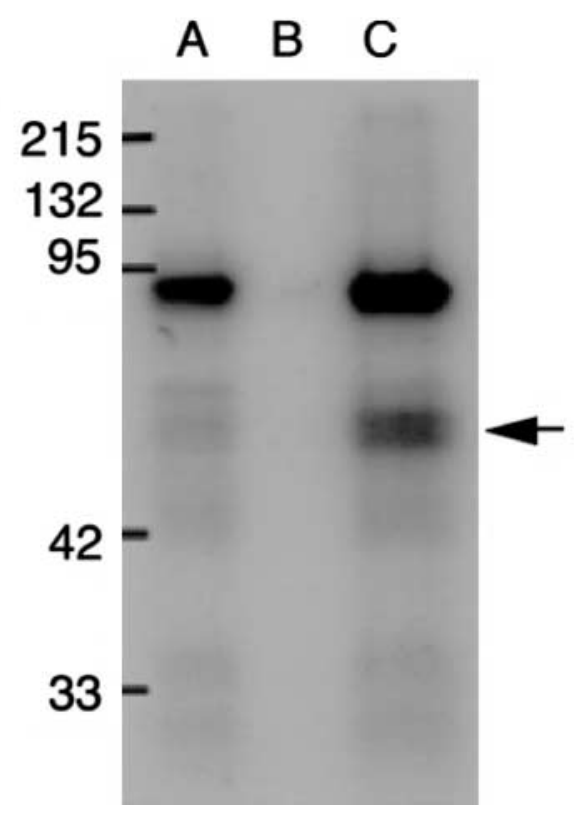

Figure 5 In vitro phosphorylation of tubulin. Kinase reactions containing GST-Fyn ${ }^{\text {5532f }}$ (lane A), tubulin (lane B), or both (lane C), were incubated in the presence of $15 \mathrm{mM}$ HEPES, $10 \mathrm{mM} \mathrm{MgCl} 2,1 \mathrm{mM}$

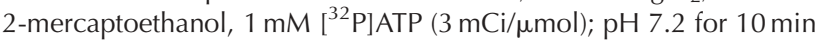
at $25^{\circ} \mathrm{C}$. The reactions were transferred into gel, dried and analyzed by autoradiography. The resulting autoradiograph demonstrates the phosphorylation of tubulin in lane C (arrow).

within the egg of $6.4 \mu \mathrm{M})$, resumed meiosis, whereas only $28 \%$ resumed meiosis at concentration of $37 \mu \mathrm{g} / \mathrm{ml}$ (within the egg $0.4 \mu \mathrm{M}$ ). Only $21 \%$ of MIl eggs injected with boiled CAF, at any injected dose, resumed meiosis (Fig. 6B, gray bars), compared with $11 \%$ of MIl eggs that resumed meiosis after being injected with KPS buffer alone (data not shown).

\section{Discussion}

\section{Are SFKs involved in spindle stability?}

We are still at the early stages of understanding the fine regulation of mitotic events. However, the importance of protein phosphorylation in general, and of tyrosine phosphorylation and dephosphorylation in particular, has become evident in the last years, and work is under way to identify and study the mitotic phosphoproteins. There is increasing evidence indicating that Src kinases play an important role in regulating mitotic events. Src kinases may be involved in phosphorylation of one or more of these mitotic phosphoproteins (Stukenberg et al. 1997, Whitaker \& Larman 2001).

In a previous study we were able to show that completion of meiosis is an SFK-dependent process (TalmorCohen et al. 2004). In the present study we demonstrated that inhibition of SFKs caused the disintegration of the spindle and dispersion of tubulin fibers in the cytoplasm. Moreover, as a result of this treatment the chromosomes were not aligned on the metaphase plate. For a successful 
A
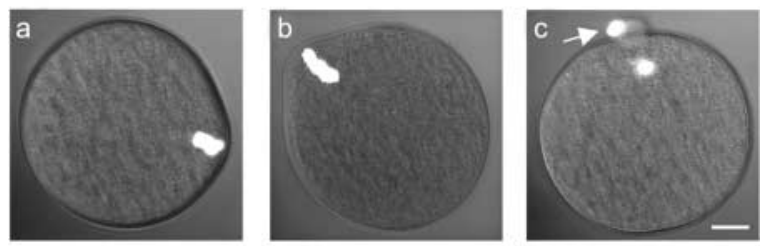

B

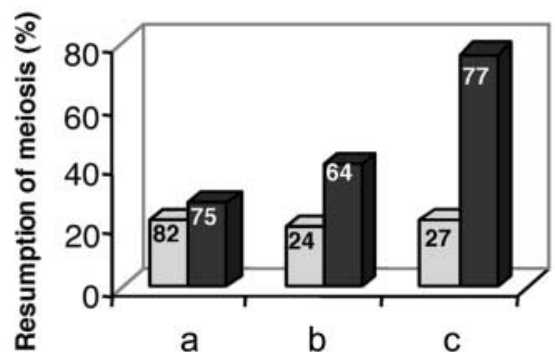

Figure 6 Completion of meiosis after CAF injection into MII rat eggs. Eggs were microinjected with CAF or with boiled CAF proteins, fixed and stained for DNA. (A) Light microscopy: MII egg (panel a); MII egg injected with boiled CAF (panel b); PBII extrusion by an MII egg injected with CAF (panel c; PBII, gray arrow). DNA was labeled by Hoechst (33342, $2 \mu \mathrm{g} / \mathrm{ml}$, dense white). The final concentration of CAF (boiled and unboiled) inside the egg's cytoplasm was $555 \mu \mathrm{g} / \mathrm{ml}$. Each image was taken at the egg's equatorial plane. Scale bar, $10 \mu \mathrm{m}$. (B) Dose-dependent completion of meiosis triggered by CAF. Eggs were microinjected with CAF (black bars) or with boiled CAF (gray bars) at various final intra-egg concentrations: $37 \mu \mathrm{g} / \mathrm{ml}$ (a); $222 \mu \mathrm{g} / \mathrm{ml}$ (b); $555 \mu \mathrm{g} / \mathrm{ml}$ (c). Data are expressed as the percentage of injected eggs that resumed meiosis successfully. Each bar represents eggs of, at least, three independent experiments. The numbers at the top of each bar are the number of injected eggs. Fisher's exact probability test was used to determine the significance of difference between the effect of $\mathrm{CAF}$ and of boiled CAF on completion of meiosis. $\mathrm{a}$ and $\mathrm{b}$, not significantly different; $\mathrm{c}$, significantly different $(P<0.001)$ from a and $\mathrm{b}$.

fertilization, the spindle of vertebrate eggs must remain stable and correctly organized during the second meiotic metaphase arrest (Terret et al. 2003, Wassmann et al. 2003). Thus, we have suggested that SFKs mediate some functions during the organization of a proper MII spindle. However, we have not yet determined whether the SFK function during fertilization controls meiotic arrest either by maintaining MPF stability or by ensuring that the spindle is properly organized during the arrest.

\section{Potential function of Fyn in microtubule signaling}

Fyn kinase is the only one of the three SFKs studied that is localized to meiotic and mitotic spindles (Talmor et al. 1998, Talmor-Cohen et al. 2004). Our findings that the proper organization of the MII spindle is an SFK-dependent process, and that Fyn kinase is localized to the MTs, lead us to investigate the involvement of Fyn in microtubule function.

Fyn kinase was found to be associated with (Katagiri et al. 1993, Marie-Cardine et al. 1995) or localized to (Ley et al. 1994, Yasunaga et al. 1996) the spindle MTs during the M-phase of various cells. In the present study, localization of Fyn to the egg's spindle MTs was observed during various stages of oocyte maturation, and during the M-phase of the meiotic division.

Our results demonstrate an association of Fyn with tubulin. The band of tubulin which has been coimmunoprecipitated by Fyn kinase appears more intense in activated eggs than in MIl-arrested eggs. We would like to suggest that during the M-phase, Fyn kinase interacts, directly or indirectly, with only a small number of tubulin units, while after egg activation, either the number of interacting units increases or the affinity between tubulin and Fyn increases, hence allowing a more efficient coimmunoprecipitation. Studies involving other cell systems have shown that mitogenic stimuli induce phosphorylation of the tyrosine residues of $\alpha$-tubulin and that the phosphorylated $\alpha$-tubulin is capable of binding the Fyn $\mathrm{SH} 2$ domain (Katagiri et al. 1993, Ley et al. 1994, Marie-Cardine et al. 1995). The spindle is a complex structure that is known to associate with a variety of proteins, including motor proteins such as kinesin (Neighbors et al. 1988) and dynein (Pfarr et al. 1990), MT-associated proteins (MAPs; Sherline \& Mascaro 1982) and $\mathrm{Ca}^{2+}$ calmodulin kinase II (Ohta et al. 1990). It has also been shown that Fyn binds MAP-2c (Zamora-Leon et al. 2001) and dynein complex (Campbel et al. 1998). The present study allows us to conclude that Fyn kinase is not merely colocalized to, but is also associated with tubulin, before and during egg activation induced by ionomycin, as demonstrated by the use of nocodazole and by coimmunoprecipitation. Fyn can phosphorylate tubulin in vitro, as implied by our in vitro phosphorylation experiment. The question whether Fyn interacts with tubulin directly or indirectly remains open. Fyn, like other SFKs, is commonly involved in multi-protein complexes involving interaction with the $\mathrm{SH} 2$ and $\mathrm{SH} 3$ domains. It is therefore possible that the localization of Fyn to the microtubules involves other MT-associated proteins.

Our findings demonstrated that CAF stimulates the completion of meiosis in rat eggs. This result should be taken with reservation because the constructed CAF is cytosolic, and as such it is incapable of bonding with a myristic acid chain. This diminished its efficiency in finding its suitable substrate, although it did not hinder its kinase activity. As a result, we were forced to employ a relatively high concentration of the activated kinase.

The CAF injection result is supported by another study concerning SFK inhibitors (Talmor-Cohen et al. 2004) and is in accordance with yet another study, performed with mouse eggs (Sette et al. 2002). In view of the CAF injection experiment and of the pronounced concentration of Fyn kinase at the spindle, we suggest that Fyn may play an important role in some aspects of spindle functions, possibly those involving the MTs themselves.

\section{Acknowledgements}

We gratefully thank Dr Leonid Mittelman for his excellent technical assistance at the confocal microscope and Mrs Ruth 
Kaplan-Kraicer for technical help and advice. We also thank Dr K Superenant, grant NSF-MCB9982377, from the University of Kansas for the gift of purified tubulin. This work was supported by a grant from the Israel Academy of Science and Humanities and from Auctorina Anstalt Foundation to $R$ Shalgi. This work is in partial fulfillment of the requirements for the PhD of A T-C at the Sackler Faculty of Medicine, TelAviv University.

\section{References}

Bagrodia S, Chackalaparampil I, Kmiecik TE \& Shalloway D 1991 Altered tyrosine 527 phosphorylation and mitotic activation of p60c-src. Nature 349 172-175.

Campbell KS, Cooper S, Dessing M, Yates S \& Buder A 1998 Interaction of p59fyn kinase with the dynein light chain, Tctex-1, and colocalization during cytokinesis. Journal of Immunology $\mathbf{1 5}$ $1728-1737$.

Courtneidge SA, Dhand R, Pilat D, Twamley GM, Waterfield MD \& Roussel MF 1993 Activation of Src family kinases by colony stimulating factor-1, and their association with its receptor. $E M B O$ Journal 12 943-950.

David-Pfeuty T \& Nouvian-Dooghe Y 1990 Immunolocalization of the cellular src protein in interphase and mitotic NIH c-src overexpresser cells. Journal of Cell Biology 111 3097-3116.

David-Pfeuty T \& Nouvian-Dooghe Y 1995 Highly specific antibody to rous sarcoma virus src gene product recognizes nuclear and nucleolar antigens in human cells. Journal of Virology 69 1699-1713.

David-Pfeuty T, Bagrodia S \& Shalloway D 1993 Differential localization patterns of myristoylated and nonmyristoylated c-Src proteins in interphase and mitotic c-Src overexpresser cells. Journal of Cell Science 105 613-628.

Eliyahu E \& Shalgi R 2002 A role for protein kinase C during rat egg activation. Biology of Reproduction 67 189-195.

Fumagalli S, Totty NF, Hsuan JJ \& Courtneidge SA 1994 A target for $\mathrm{Src}$ in mitosis. Nature 368 871-874.

Kaplan KB, Swedlow JR, Varmus HE \& Morgan DO 1992 Association of $\mathrm{p} 60^{\mathrm{c}-\mathrm{src}}$ with endosomal membranes in mammalian fibroblasts. Journal of Cell Biology 118 321-333.

Katagiri K, Katagiri T, Kajiyama K, Yamamoto T \& Yoshida T 1993 Tyrosine-phosphorylation of tubulin during monocyte differentiation of HL-60 cells. Journal of Immunology $\mathbf{1 5 0}$ 585-593.

Kypta RM, Goldberg Y, Ulug ET \& Courtneidge SA 1990 Association between the PDGF receptor and members of the Src family tyrosine kinases. Cell 62 481-492.

Ley SC, Marsh M, Bebington CR, Proudfoot K \& Jordan P 1994 Distinct intracellular localization of Lck and Fyn protein tyrosine kinases in human T lymphocytes. Journal of Biological Chemistry $125639-649$.

Marie-Cardine A, Kirchgessner H, Meuer SC \& Schraven B 1995 Human T lymphocyte activation induces tyrosine phosphorylation of $\alpha$-tubulin and its association with the $\mathrm{SH} 2$ domain of the p5 $9^{\mathrm{c}-\mathrm{fyn}}$ protein tyrosine kinase. European Journal of Immunology 25 3290-3297.

Moasser MM, Srethapakdi M, Sacher SK, Kraker AJ \& Rosen N 1999 Inhibition of Src kinases by a selective tyrosine kinase inhibitor causes mitotic arrest. Cancer Research 59 6145-6152.

Neighbors BW, Willians RC \& Mcintosh JR 1988 Localization of kinesin in cultured cells. Journal of Cell Biology 106 1193-1204.

Ohta Y, Ohba T \& Miyamoto E $1990 \mathrm{Ca} / \mathrm{calmodulin}$-dependent protein kinase II: localization in the interphase nucleus and the mitotic apparatus of mammalian cells. PNAS $875341-5345$.
Pfarr CM, Coue M, Grissom PM, Hays TS, Porter ME \& Mcintosh JR 1990 Cytoplasmic dynein localizes to kinetocores during mitosis. Nature 345 263-265.

Roche S, Fumagalli S \& Courtneidge SA 1995a Requirement for Src family protein tyrosine kinases in G2 for fibroblast cell division. Science 269 1567-1569.

Roche S, Koegl M, Barone MV, Roussel MF \& Courtneidge SA 1995b DNA synthesis induced by some but not all growth factors requires Src family protein tyrosine kinases. Molecular Cell Biology 15 $1102-1109$.

Rongish BJ \& Kinsey WH 2000 Transient nuclear localization of Fyn kinase during development in Zebrafish. Anatomical Record $\mathbf{2 6 0}$ 115-123.

Rufas O, Fisch B, Ziv S \& Shalgi R 2000 Expression of cadherin adhesion molecules on human gametes. Molecular Human Reproduction 6 163-169.

Sette C, Paronetto MP, Barchi M, Bevilacqua A, Geremia R \& Rossi P 2002 Tr-kit induced resumption of the cell cycle in mouse eggs requires activation of a src-like kinase. EMBO Journal $\mathbf{2 1}$ 5386-5395.

Sherline P \& Mascaro RN 1982 Epidermal growth factor induces rapid centrosomal seperation in HeLa and 3T3 cells. Journal of Cell Biology 93 507-511.

Stukenberg PT, Lustig KD, McGarry TJ, King RW, Kuang J \& Kirschner MW 1997 Systematic identification of mitotic phosphoproteins. Current Biology 7 338-348.

Superti-Furga G \& Courtneidge SA 1995 Structure-function relationships in Src family and related protein tyrosine kinases. Bioessays $17321-330$.

Talmor A, Kinsey WH \& Shalgi R 1998 Expression and immunolocalization of $\mathrm{p} 59^{\mathrm{c}-\mathrm{Fyn}}$ tyrosine kinase in rat egg. Developmental Biology 194 38-46.

Talmor-Cohen A, Tomashov-Matar R, Eliyahu E, Shapiro R \& Shalgi R 2004 Are Src family kinases involved in cell cycle resumption in rat eggs? Reproduction 127 455-463.

Taylor SJ \& Shalloway D 1993 The cell cycle and c-Src. Current Opinion in Genetic and Development 3 26-34.

Taylor SJ \& Shalloway D 1994 An RNA-binding protein associated with $\mathrm{Src}$ through its $\mathrm{SH} 2$ and $\mathrm{SH} 3$ domains in mitosis. Nature $\mathbf{3 6 8}$ 867-871.

Terret ME, Wassmann K, Waizenegger I, Maro B, Peters JM \& Verlhac MH 2003 The meiosis I-to-meiosis II transition in mouse oocytes requires separase activity. Current Biology 20 1797-1802.

Wassmann K, Niault T \& Maro B 2003 Metaphase I arrest upon activation of the Mad2-dependent spindle checkpoint in mouse oocytes. Current Biology 18 1596-1608.

Whitaker M \& Larman MG 2001 Calcium and mitosis. Cell Development Biology 12 53-58.

Yasunaga $M$, Yagi $T$, Hanzawa $N$, Yasuda $M$, Yamanashi $Y$, Yamamoto T, Aizawa S, Miyauchi Y \& Nishikawa S 1996 Involvement of Fyn tyrosine kinase in progression of cytokinesis of B lymphocyte progenitor. Journal of Cell Biology 132 91-99.

Zamora-Leon SP, Lee G, Davies P \& Shafit-Zagardo B 2001 Binding of Fyn to MAP-2c through an SH3 binding domain. Regulation of the interaction by ERK2. Journal of Biology and Chemistry 276 39950-39958.

Zhao V, Sudol M, Hunafusa H \& Krueger J 1992 Increased tyrosine kinase activity of c-src during calcium-induced keratinocyte differentiation. PNAS 89 8298-8302.

Received 11 March 2004

First decision 7 May 2004

Accepted 9 June 2004 